\title{
RESISTING THE MELTING POT: THE LONG TERM IMPACT OF MAINTAINING IDENTITY FOR FRANCO-AMERICANS IN NEW ENGLAND
}

\author{
Mary MacKinnon and Daniel Parent \\ Department of Economics \\ McGill University \\ December 2005 \\ "I'm not a beatnik, I'm a Catholic." -Jean-Louis (Jack) Kerouac
}

\begin{abstract}
Approximately 1 million French-Canadians moved to the United States, mainly between 1865 and 1930, and most settled in neighboring New England. In 1900 almost a fifth of all persons born in French Canada lived in the U.S. These migrants exerted considerable efforts to maintain their language and to replicate their home country institutions, most notably the schooling system, in their new country. For decades, this resistance to assimilation generated considerable attention and concern in the U.S. The concerns are strikingly similar to those often invoked today in discussions of immigration from Hispanic countries, notably Mexico. Mexicans may not be assimilating into mainstream America as European immigrants did. We look at the convergence in the educational attainment of French Canadian immigrants across generations relative to native English-speaking New Englanders and to European Roman Catholic immigrants. The educational attainment of Franco-Americans lagged that of their fellow citizens over a long period of time. By the time of the 2000 Census, they appear to have largely achieved parity. The effects of World War II, especially military service, were very important in speeding up the assimilation process through a variety of related channels: educational attainment, language assimilation, marrying outside the ethnic group, and moving out of New England. Economic assimilation was very gradual because of the persistence of ethnic enclaves.
\end{abstract}

The authors thank participants at the Canadian Economics Association, Canadian Network for Economic History, the Société canadienne de science économique conferences, and workshop participants at McGill, UBC, Trinity College (Dublin) and UC-Berkeley for valuable comments. Financial support for this project came from the SSHRC. 


\section{I) Introduction}

Americans have both welcomed and feared immigrants, with the balance of attitudes shifting depending on the perceived characteristics of the group in question and economic conditions in the United States. Of continuing concern is whether migrants from other parts of the Americas are more or less desirable than overseas migrants. In 1885 (23 Sept. p. 4), the New York Times editorialist stated In such towns as Fall River and Holyoke the French Canadians have nearly shouldered out the native American operatives [...] They have crowded the Irish very hard, and they form a much more intractable element in the social problem [...] Their dwellings are the despair of the sanitarians and themselves the despair of social philosophers [...] They are the Chinese of New-England inasmuch as they seem rarely to strike root in our soil. Whatever may be the fate of the Irish immigrant there is always the hope that his children and grandchildren may be assimilated with the native population. [...] His interest in the land of his birth is chiefly sentimental and is expressed in occasional contributions to the emergency fund. But even if the French Canadian leaves his bones here his thoughts all lie beyond the Canadian border [...] Add to this feeling of alienism that he is absolutely unenterprising, and it becomes evident that he must be a troublesome element in the population.

In the late 1870s and 1880s, newspaper editorialists and government officials routinely denounced the arrival of illiterate Roman Catholics from the poor farms of Quebec. An academic article documenting the quantitative importance of, and the problems generated by, the substantial influx of French-Canadians into New England [MacDonald, 1898] presents a more sympathetic view. MacDonald noted that "Nowhere do [French Canadians] seem to be looked upon, as a class, with entire favor, and in private are often spoken of with contempt; but their work is necessary, their trade is important, and their political support not to be despised." [p. 278] He predicted that despite their unfavorable group characteristics, the French Canadians, like all other immigrants, would eventually assimilate. MacDonald's assessment was made under the belief that the inflow was in decline [p. 257]. In fact the flow persisted for another thirty years, but we find evidence supporting the prediction of eventual assimilation.

This paper looks at the movement of approximately 1 million French-Canadians from Canada to the United States. The bulk of the migration occurred between the end of the Civil War and 1930, 
with most settling in neighboring New England. In 1930, approximately two-thirds of first and second generation French Canadians lived in New England [Truesdell, 1943].

A little over one hundred years later, Mexican immigration attracts similar attention. Concerns over the impact of recent inflows range from labor market repercussions in terms of wages and jobs [Borjas, 2003], social program usage [Borjas and Trejo, 1993], educational outcomes of native Americans [Betts and Lofstrom, 1998], to overall "social" impacts [Huntington, 2004]. In a controversial article, Huntington [2004] asserts that the current episode of Mexican immigration is a unique event in United States history. ${ }^{1}$ Much has been said about the contemporary situation, but it is still too early to determine to what extent Mexican-Americans will eventually assimilate, socially and economically, into mainstream society. ${ }^{2}$

There was prolonged concern about French Canadian immigration to New England. ${ }^{3}$ Several of the factors Huntington sees as unique to Mexican immigration (contiguity, regional concentration, persistence, and historical presence) bear a strong resemblance to French Canadian migration, certainly much more than for migrants from southern and eastern Europe. Unlike European immigrants, for many decades virtually any French Canadian could move to the U.S. or back home: time and travel costs were low and border controls minimal. As Theriault [1951, p. 2] notes: "From the point of view of resistance to assimilation the Franco-Americans appear to be most nearly comparable to the SpanishAmericans of the Southwest, with whom they also share the unique distinction among American immigrant groups of proximity to their country of origin."

Relative to the more recent flows of Mexican migrants, French-Canadian immigrants exerted considerable efforts to maintain their language and to replicate their home country educational and ecclesiastical institutions. French Canadians established many "national" parishes where both church and school were bilingual or French and the priest was usually from French Canada. The IrishAmericans who ran the U.S. Roman Catholic Church were assimilationist. They often opposed the creation of French-Canadian parishes and when possible assigned European francophone (or even Irish) priests who would discourage the maintenance of Canadian customs. French Canada's Roman Catholic

\footnotetext{
1"Contemporary Mexican ... immigration is without precedent in U.S. history. The experience and lessons of past immigration have little relevance to understanding its dynamics and consequences. Mexican immigration differs from past immigration and most other contemporary immigration due to a combination of six factors: contiguity, scale, illegality, regional concentration, persistence, and historical presence" [p. 33].

${ }^{2}$ Although see Trejo [2003] for a look at the intergenerational progress made by Mexicans of recent cohorts. ${ }^{3}$ Concerns about the French Canadians remaining separate persisted for many years. In 1942, F.D. Roosevelt told Canadian Prime Minister Mackenzie King that despite recent progress he saw a need for greater assimilation of French Canadians in New England [Bothwell, 1992, p. 4].
} 
Church played an active role in helping Franco-Americans achieve their goal of "ethnic survival" by sending large numbers of priests, nuns, and teaching brothers.

At the peak in 1900, a substantially higher proportion of all Canadian born francophones lived in the U.S. (19 percent) than was true for the Mexican born in 2000. We have no way of telling whether 2000 will turn out to be near the peak for a Mexican-born presence in the U.S. By 1930, the proportion of Canadian born francophones living south of the border had dropped to 11 percent [Truesdell, 1943 and Urquhart and Buckley, 1965, p. 18].

Franco-Americans were demographically important especially in New England towns. Nearly 5 percent of the 1900 population of New England was French Canadian born, and 9 percent were first or second generation French Canadian. In 1930, 3 percent of New England's population was French Canadian born, 9 percent first or second generation immigrants (including those with only one parent born in Canada) [Truesdell, 1943, p. 77, and US Census]. As Map 1 shows, in 1910-1920 the population of many counties was at least 10 percent first or second generation French Canadian (and 20 percent or more in roughly half of those counties). The majority of French Canadians lived in a relatively small set of counties, which is likely more important for the creation of ethnic enclaves. In most of these counties they made up at least 10 percent of the total population.

Of course, an understanding of the assimilation path of Franco-Americans is not a sure guide to future outcomes for Mexican immigrants. World crises of the 1930s and 1940s had the unintended effect of speeding French Canadian assimilation into U.S. society. Continuous peace and prosperity could have substantially slowed down these transformations. If Mexico experiences little economic growth while the U.S. prospers greatly, pressures to move may persist for much more than sixty years.

Supply limitations were a factor for French Canadian much more than Mexican migration. The total francophone population of Canada in 1900 was only 29 percent of the total population of New England and 2 percent of the entire U.S. population. In 1930, the French origin population in Canada was 36 percent of the total population of New England, and still 2 percent of the entire US population [Urquhart and Buckley (eds.), 1965, p.18 and U.S. Population Census of 1930, Vol. II, p. 35]. In 2004, the population of Mexico was 35.8 percent of the total population of the United States [Central Intelligence Agency, World Factbook].

Virtually any French Canadian could cross the border up to 1917, and minimally literate French Canadians could do so until 1930; officially the current flow from the south is tightly regulated. French Canadians showed marked reluctance to take out American citizenship, even though they were free to do so. The French Canadian experience sheds no light on the impact of having a large number of 
illegal, but long-resident, immigrants who cannot apply for citizenship. What it can shed light on is the impact of forming ethnic enclaves whose sustained existence is supported by the proximity of the source country.

The goal of the paper is to look at French Canadians' convergence across generations towards the patterns seen for native white English-speaking New Englanders and for European Roman Catholic immigrants. ${ }^{4}$ We focus principally on educational attainment as a measure of assimilation. In 1970, Franco-Americans still lagged their English mother-tongue fellow citizens by at least a full year of schooling. Inter-generational progress was considerably slower than for Italians in New England, despite the fact that Italian immigrants came to the United States with lower levels of schooling. By the end of the century, however, younger cohorts of French Canadian ancestry New England residents achieved near parity in educational attainment. Marriage outside the ethnic group was important in bringing about convergence. ${ }^{5}$

As social historians have argued [Roby, 2000, pp. 372-377, 384-389], World War II was a pivotal event which accelerated the assimilation of Franco-Americans through exogamy and geographic mobility. The paper combines evidence from the 1980, 1990 and 2000 Census to investigate the sources of progress both for those born in the 1910s and 1920s, and their children. Military service was a major factor accelerating the assimilation process. New England born men of French Canadian ancestry had high rates of military service. World War II service, in particular, directly or as a result of increased education made possible by veterans' benefits, resulted in higher rates of residence outside New England, marriage outside the ethnic group, and lower probabilities of reporting French as the home language. We also observe declining enrollments in private (mainly parochial) schools for children born in the post-war years. By 2000, French Canadian ancestry children were no more likely than other New Englanders to attend private school. This was likely more a result than a cause of declining attachment to the Franco-American identity.

The paper is structured as follows. Section 2 documents French-Canadian immigration patterns. Section 3 describes the immigrants' attempts to insulate themselves from New England society by establishing their own school system, and explains how these schools differed from the Quebec system. In Section 4 we explain the data used and in Section 5 show empirical results on

\footnotetext{
${ }^{4}$ The main previous work of this type is Borjas (1994), which compares the experience of many immigrant groups. Borjas does not differentiate French Canadians from English Canadians. When looking at educational attainment the distinction is crucial.

${ }^{5}$ Individuals reporting their second ancestry is French Canadian are assumed to be products of mixed marriages.
} 
educational attainment by ethnic group. Section 6 considers the ways World War II helped to break up the Franco-American enclaves. We provide concluding remarks in Section 7.

\section{II) Immigration Patterns}

In the nineteenth century, the rate of natural increase among the francophone Canadian population was high, and possibilities to obtain good farmland were low. While urban centers in Canada absorbed some of those eager to leave agriculture, the U.S. offered a much greater number of manufacturing jobs. Textile mill owners recruited some of the earliest groups of migrants [Roby, 2000, p. 27]. While the early French Canadians of New England were derided as the "Chinese of Eastern North America," ${ }^{16}$ unlike most Chinese immigrants to the western states, it was common for French Canadian families, as well as single men, to move, with young adolescents readily able to find work in the mills. ${ }^{7}$ Travel costs, in both time and money, were minimal for French Canadians moving to New England. One day and (around 1900) at most five dollars (about a week's wages for a low skilled man in Quebec) was sufficient to get to the mill towns of southern New England [Green, MacKinnon, and Minns, 2005]. While many participants in streams of immigration come with the intention of returning home, it was far easier for French Canadians than for European immigrants to actually return. The cost of an Atlantic voyage was more like $\$ 25$ and travel time around two weeks. ${ }^{8}$

Whenever there was a downturn in the New England mill towns, Canadian authorities predicted both the end of the outflow, and a massive return by the unemployed. There were repeated attempts to convince emigrants either to move to the Canadian west or to return to Quebec to take up farms in areas north of the St. Lawrence valley. If going "home" is an easy option, then the willingness to make both symbolic and practical breaks with the past is likely lessened. French Canadian migrants in New England took out American citizenship less often than most other immigrants. ${ }^{9}$ It is extremely doubtful that it was ties to Queen Victoria or her descendants that they were unwilling to renounce. For the Roman Catholic Church in Quebec (and New England), faith and language were inextricably linked. It was easy to encourage convents to set up schools in the "Little Canadas". The need was understood to be great, and the cost of sending Canadian-born nuns to New England was minimal.

\footnotetext{
${ }^{6}$ French Canadians were not only compared with the Chinese. Another New YorkTimes editorial (June 6, 1892) noted that "No other people, except the Indians, are so persistent at repeating themselves. Where they halt they stay, and where they stay they multiply and cover the earth." The Massachusetts Bureau of Statistics of Labor Reports [1881 and 1882] report on hearings studying French Canadian immigrants. ${ }^{7}$ Roby [1993, pp. 13-27] discusses the earliest phases of migration. The most detailed account of family employment in the textiles industry is Hareven [1982].

${ }^{8}$ According to the Immigration Commission, in 1908 , almost $60 \%$ of the sampled French Canadian male employees living in the U.S. for ten years or more had made at least one trip home. Not quite a third of the Italian men had been back [Immigration Commission, Vol. 20, pp. 983, 994, 995].

${ }^{9}$ In 1908, 28\% of French Canadian foreign born adult men in the U.S. for 10 years or more were fully naturalized, while $42 \%$ of Italians were [Immigration Commission, Vol. 20, pp. 1316, 1324-25].
} 
From 1917, migrants from Canada were subject to the U.S.-imposed literacy test, and some French Canadians failed it [Ramirez, 2001]. There had been very considerable improvements in literacy among the French Canadian population since the 1870s, so that the new test did not have a major negative impact on the possibility of getting into the States. ${ }^{10}$ The slower growth of the New England textile industry was probably more important in limiting migration to New England in the 1920s.

To get an idea of the gross yearly flows into New England from French Canada, we combine arrival years reported in the 1900-1930 census by French Canadians living in New England and plot their distribution (see Figure 1). This procedure misses those who had died or returned to Canada by each census year, and correspondingly over-weights recent in-migrants who might be passing through. ${ }^{11}$ It does, however, highlight that MacDonald (1898) was incorrect in thinking the immigration phase was over by the late 1890 's. Fairly high rates of immigration continued until roughly 1915 . Immigration rates remained very low throughout the depression and World War II. ${ }^{12}$ During the 1930s, there was almost no legal, or probably illegal, migration of French Canadians: visas were rarely granted to prospective workers and unilingual immigrants stood little chance of finding any work [Gemery, 1994]. Unlike Mexicans, few French Canadians were deported, nor was there any substantial voluntary return to Canada. During the war, it was difficult to leave Canada as workers in key sectors (including agriculture) needed permission to resign from their job [Lines, 1978, D.B.S., 1945]. Young men who moved illegally would have been liable for the American draft. ${ }^{13}$

Mexican migrants of the war and immediate post-war period generally became agricultural workers: from the mid-nineteenth century onwards, this was rarely the occupational outcome for French Canadian emigrants. The manufacturing sector in Quebec grew briskly, especially in the 1940s. Between 1941 and 1961, the number of wage-earners in manufacturing rose by about 45\%, while in New England, the increase in manufacturing employment was less than 25\%. The New England urban labor market was still far larger, but the relative opportunity for employment in reasonably well-paid non-agricultural jobs rose sharply in Quebec. Contacts with their cousins in New England were also weakening. After 15 years of migration restrictions brought about by depression and war, it is doubtful that in the 1950s many Franco-Americans would have strenuously exerted themselves to help resettle new arrivals. The invisible chains linking New England and Quebec were broken and there were few compelling reasons to re-forge them. Wartime service and economic opportunities elsewhere tended to break up the francophone enclaves in New England. After the war, low rates of immigration coupled

\footnotetext{
${ }^{10}$ Only about half of working-age francophone men in Canada could read and write in 1871.

${ }^{11}$ To avoid double counting, we use the 1900 census for those who arrived before 1896, the 1910 census for those arriving between 1896 and 1905, the 1920 census for those arriving between 1906 and 1915 and the 1930 census for all arrivals between 1916 and 1930. Except for 1926 to 1930, we do not use the 5 years leading up to and including each census year to minimize the likelihood of picking up short-term residents. There is clearly considerable year heaping in recalling the date of immigration.

${ }^{12}$ Paquet and Smith (1983) computed decadal net migration rates suggesting more substantial flows to the United States in the 1920s, but many of these migrants were headed for Michigan.

${ }^{13}$ During World War II, Franco-Americans were far more likely to serve with the U.S. forces than French Canadians were to serve with the Canadian military (Lemieux and Card, 2001).
} 
with suburbanization of the population made it much harder to maintain viable French-language institutions (newspapers, schools, churches) [Roby, 2000, pp 353-475].

Over time, discussion developed within the Franco-American community about the desirability of taking out American citizenship [Petrin, 1990]. The same reports that noted the number of children at (bilingual) parochial schools also listed the number of voters and boasted of the city councilors and state legislators of French background [Hamon, 1891, Belanger, 1935]. To remain distinct (protect the right to bilingual schooling, for example), it helped to have a voice in the American political process. In 1930, over half of the French Canadian born adult men in the US were citizens. However, proportions naturalized were generally lower in the New England states than in the rest of the U.S. [Truesdell, 1943, pp. 111, 117].

\section{III) Franco-American and French-Canadian Educational Institutions}

As Brault [1986, p. 73] stresses "the cornerstone on which the Franco-American school was built was the profound conviction that abandoning the French language was tantamount to abandoning the Catholic faith." While the earliest schools for Franco-American children were set up by mills, as immigration continued and many French Canadians located in a fairly small set of towns, religious orders took over or established parochial schools.

Parochial schools used the French language in a French Canadian environment, where the teachings of the Roman Catholic Church were paramount. The use of French raised the greatest concerns among native Americans. English-language parochial schools were suspect (but already longestablished by Irish immigrants); French-language parochial schools were clearly dangerous.

Recognition of parochial schools was an issue early on precisely because there was no instruction in English [Brault, 1986, p. 75]. The authorities requiring school attendance accepted bilingual parochial schooling. From about 1900 to the 1950s, most parochial schools taught half a day in French, half a day in English. French was used for catechism, Bible study, Canadian history, art, and music (and for prayers). Reading, writing, arithmetic, American history, geography, civics, and hygiene were taught in English [Brault, 1986, p. 95]. Usually Canadian religious taught in French while Americans taught in English. ${ }^{14}$ The short-term goals for religious instruction were to prepare the younger children for First Communion (around age 7), and the older children for Confirmation (around age 12).

It was not customary for Franco-Americans to attend high school or college. Initially, the

\footnotetext{
${ }^{14}$ Where Franco-Americans were a long settled (and small) minority, by the 1930s parochial schools were moving away from French-language instruction. This was the case in Newburyport, MA, where there were about 1,500 persons of French Canadian origin out of a total population of roughly 17,000 [Warner and Srole, 1945, pp. 28, 235, 241-2].
} 
options for post-primary education were U.S. public schools, English language Catholic institutions, or (in Canada) convent boarding schools for girls or church-run "Classical Colleges" for boys. The 8-year Classical College curriculum led roughly to a B.A., with the first four years corresponding to high school education. This system was not publicly funded. With increased demand by Franco-Americans for post-elementary but not secular schooling in New England, several convents began to offer schooling for teenaged girls. The first U.S. Classical College, Assumption College, was established in Worcester, MA, in 1904. By the late 1930s instruction at Assumption was bilingual [Brault, 1986, p. 98]. ${ }^{15}$

Franco-Americans tried hard to re-create the educational institutions of French Canada. Three main differences in the educational environment made the New England "flavor" different and played key roles in the eventual absorption of Franco-Americans into mainstream society. First, except in the very early years, all the U.S. schools provided substantial instruction in English. Second, all children were eligible to enroll in the public school system. Franco-Americans were subject to pressures from native Americans to enroll their children in the public schools at the same time that their priests preached the importance of sending the children to the parochial school. ${ }^{16}$ Although parents in urban Quebec could in principle enroll their children in English-speaking Catholic schools, in practice few did. Finally, there were no compulsory schooling laws in Quebec until the 1940s. While in New England manufacturing towns it may have been fairly easy for children just below the school-leaving age to evade compulsory schooling laws, by the early twentieth century there was strong external pressure to ensure attendance for seven or eight years.

\section{IV) Data}

Previous quantitative studies of French Canadians in New England have generally focused on a small set of communities (as in Theriault [1951]). To get a broader view, we use the IPUMS of the United States Census for most $20^{\text {th }}$ Century census years as well as the 2000 Census to create samples of New England residents of several ethnic backgrounds and also samples of New England born individuals of French Canadian origin living in other parts of the U.S. We focus on New England: the concentration of French Canadians was highest there and the institutions necessary to permit the maintenance of a separate identity flourished. In Michigan or California, living in French was really not

\footnotetext{
${ }^{15}$ The 1935 Guide Franco-Americain included advertisements for secondary and post-secondary bilingual and French-language institutions on both sides of the border. Some offered commercial training as well as the traditional academic curriculum.

${ }^{16}$ An English-language parochial school might also exist. In Newburyport MA in the early 1930s, only a quarter of elementary school age French Canadian children attended the French parochial school [Warner and Srole, 1945, p.233].
} 
an option. Residents of Fall River or Woonsocket could more plausibly act as if U.S. residence was temporary, or that New England was a southern extension to Quebec and Acadia.

We put a strong emphasis on 1970 U.S. Census data. We are interested in the long-term effect of French-Canadian heritage, and 1970 is roughly forty years after the border closed. The Form 2 samples of the 1970 Census contain information about birthplace and mother tongue for respondents and both their parents. ${ }^{17}$ The 1980 to 2000 U.S. Censuses are less appropriate for the purpose of evaluating intergenerational progress because they contain only the self-reported first and possibly second ancestry of the respondent. The absence of information about parental birthplace precludes looking at convergence across generations. By 2000, few Franco-Americans under 70 had been born in Canada. We pick up some third (or even higher) generation descendants of immigrants with the "ancestry" response, but we cannot separate generations. Respondents could answer "American" to the ancestry question, and so some are assigned to the comparison group when they should be in the French-Canadian group. However, these censuses allow respondents who never spoke French to identify with the French Canadian ethnic group and thus we can identify links between education, mobility, not speaking French at home, and exogamy (which we define as second reported ancestry French Canadian).

The 1900, 1910, 1920, and 1930 Census IPUMS (the latter being the recent preliminary release) are used to assess literacy and school enrollment. The 1940 Census includes most of the relevant variables also in the 1970 Census. This allows us to study the educational outcomes of FrancoAmericans shortly after the end of the migration period. The sample size is restricted because only "sample-line" members (one per household) were asked questions on mother tongue and parents' birthplace. We added observations to the sample-line member sample by looking at each household member's relationship to the head of the household and to the sample-line individual. For example, if a non sample line member is the son of the head of household and the head's wife is the sample-line individual, and her mother tongue is French, then the son is considered to be a Franco-American. ${ }^{18}$

\section{V) Educational Attainment 1910-2000}

While several European immigrant groups were mainly Roman Catholic, we concentrate on Italians as the main comparison for French Canadians because there were almost as many persons of

\footnotetext{
${ }^{17}$ Except for the basic descriptive statistics shown in Table 3, we exclude both respondents who report French as their mother tongue but birthplace in any French-speaking country other than Canada and those reporting parental birthplace in a French-speaking country other than Canada. Few observations were deleted - to be francophone in New England virtually always was to be of French Canadian descent.

${ }^{18}$ When the sample line individual in the household is a non-relative, we cannot infer anything about ethnic origins, unless someone in the family group was born in French Canada.
} 
Italian as French Canadian origin in New England in $1930 .{ }^{19}$ By the early twentieth century a high proportion of the "Irish" were grandchildren or great-grandchildren of immigrants, and almost always listed English as their mother tongue, so they cannot be distinguished in the census. Tables 1 and 2 show the fractions of the 1970 New England population by age group reporting French or Italian as their mother tongue. As for the total population in 1930, in the 1970 census somewhat more of New England's adults report French Canadian than Italian origin.

We want to assess the impact on successive generations of holding onto the mother country institutions, and language is a critical part of those institutions (Chiswick and Miller [2003]). While using mother tongue as the identifier of ethnic background excludes some grandchildren of French Canadian migrants because they had never spoken French, the characteristics of those who remained part of the French-speaking community should give us a "most adverse case" perspective on long term assimilation.

The most striking feature of Tables 1 and 2 is that while broadly similar fractions of New England residents reported French or Italian as mother tongue, clear differences emerge once the samples are broken down by nativity status and age. Given low levels of immigration after 1924 and 1930, and declines in the use of French and Italian among longer-settled families, we would expect there to be fewer French and Italian speakers among younger than older adults. The contrast is much sharper for Italians, suggesting greater language assimilation by younger cohorts. Table 1 also emphasizes that many francophones were long-settled in the U.S. Roughly a third of the group born around 1920 were (at least) grandchildren, not children, of French Canadians.

Table 3 shows one of the main results in the paper, which continues to hold once we control for measurable characteristics in regression analysis. In 1970, even among the youngest adults and those whose parents were both born in the U.S., Franco-Americans' average educational attainment lagged that of white English-speakers by over one full year. Not surprisingly, the largest deficit in educational attainment is observed among first generation immigrants, many of whom attended school in Canada. That immigrants' average years of schooling were "capped" around 9 is not a surprise; the schooling system in French Canada long imposed a hard ceiling except for the wealthy.

By tracing the literacy, school enrollment, and type of school attended of Franco-Americans and Italian-Americans relative to English speakers, we can get a better sense of why educational

\footnotetext{
${ }^{19}$ While there were 4.5 million Italian immigrants and their children in the US in 1930, only 660 thousand lived in New England. 740 thousand out of a total of 1.1 million French Canadians were in New England [US Census of Population, Vol. II, Table 7]. Italians were more concentrated in Connecticut and Massachusetts than were the French Canadians. Only about 360 thousand Polish immigrants and their children lived in New England.
} 
assimilation proceeded slowly up to World War II. Retrospective reports collected in 1970 about total years of school attendance by each age group match up quite well with current responses in earlier census years about children's school attendance.

Figures 2a and b show school attendance rates for three groups of New Englanders in 1910, and for Quebec francophones in $1901 .{ }^{20}$ French-speaking children were more likely to attend school in New England than had been the case a decade earlier in Quebec, but as soon as French boys were considered able to work, almost all left school. A broadly similar age pattern is observed for girls, but with both a perceptible drop at around the age of 10 and with somewhat more girls than boys continuing at school into their mid-teens. While early employment or domestic duties would have pulled most of these children out of public schools, attendance at parochial schools is a factor behind the extremely rapid drop in attendance rates after age 13. The "next step" of attending a convent or classical college was available to only a few individuals. Moving on to a public high school would have rarely been encouraged, and the educational preparation in most parochial schools may not have provided an adequate academic background.

The limited education of French-speakers in New England is consistent with the finding that when the American secondary education system started its considerable expansion (1910 to the late 1920s), New England lost its national lead in the fraction of adolescents graduating from high school [Goldin, 1998, Goldin and Katz, 1999]. With most French-speaking children quitting school by age 14 or 15 , and with a continuing flow of minimally educated immigrants from Quebec, the relative position of New England was likely to deteriorate.

As Figure 2b shows, Franco-American girls started school at the same age as English-speaking native born girls. French speaking boys, however, not only left school earlier than the English-speaking natives, they also started later, with near-universal attendance reached at age 9 . We do not see this contrast in Quebec where few young children of either sex were at school.

School attendance rates for French-speaking children, especially boys, were clearly lower than the rates recorded for Italian-speaking children. We are not observing a common immigrant Roman Catholic pattern. While the attendance rates for older Italian-speaking girls were almost as low as for French-speaking girls, they were higher for younger girls, and always higher for boys. The New England school attendance patterns in 1910 do not reflect the relative literacy rates of the two groups of

\footnotetext{
${ }^{20}$ The currently available IPUMS 1 in 200 sample from the US 1900 census does not include enough French and Italian children in New England for us to use it. No sample of the 1911 Canadian census is yet available. At least in rural areas, school attendance rates would have been little higher in 1911 than in 1901 . We have 26973 (New England) and 24956 (Quebec) observations of individuals aged 5 to 21.
} 
immigrant adults, as Figures 2c and d show. In 1910, the literacy rate of French-speaking adults in New England was similar to that of adults in rural Quebec a decade earlier. On both sides of the border, French-speaking men were less likely to be able to read and write than their wives and sisters. In 1910, even among young males, close to 20 percent were illiterate, with the ability to read and write falling sharply for men born before about 1860 . However, relative to Italian immigrants, French Canadians appear well educated, with a sharper contrast for women than men. Despite the limited or non-existent academic background of many Italian parents, their children spent more years in school than did Frenchspeaking youngsters.

The 1910 census did not report the type of school children attended, but in December 1908 the Immigration Commission surveyed public and parochial schools in several New England cities with a substantial French Canadian population. In each of the surveyed cities where there was a substantial French-Canadian presence, schoolchildren whose fathers were French Canadian were strikingly likely to attend a parochial school [Immigration Commission, Vols. 30-32]. Perlmann (1988) stresses that Italians rarely sent their children to parochial school, and this is what we see throughout New England. Only Polish children (who are not found in large numbers in the cities where the French Canadians lived in 1908) were as likely as French Canadians to attend parochial schools.

Figures 3a and 3b compare school attendance rates in 1940/41 to show the progress made by second generation Franco-Americans and Italian-Americans relative to English speaking white Americans. By 1940 school attendance rates up to age 15 are virtually the same for all three groups of Americans, at which time the Franco attendance rate drops precipitously, much more sharply than for Italian-Americans. ${ }^{21}$ This pattern suggests that compulsory school attendance was more of a constraint for Franco-Americans. Progress had occurred between 1910 and 1940 in school participation rates of younger Franco-Americans relative to U.S. Anglos, but few Franco-Americans graduated from high school at a time when roughly half of the Anglos did.

In 1970, relative enrollment rates for Franco-Americans still drop after age 16 (Figures 4a and b), although not as much as in earlier years, particularly for boys with U.S. born parents. By the year 2000, Figure 5a suggests Franco-American males' college enrollment rates were still lower than for non Francos, but virtually complete catch up for females had taken place (Figure $5 b$ ). Figure $5 c$ shows the proportion of New England students attending private schools in 1970 and 2000. While in 1970 few parochial schools still taught in French, roughly half of the U.S. born French mother tongue children

\footnotetext{
${ }^{21}$ Borjas (1994) reports that a 20\% higher literacy rate in 1910 among an immigrant group was associated with an average of one more year of schooling for the native born children of that ethnic group in 1940. This is far from what we see in a comparison of French Canadians and Italians.
} 
attended parochial elementary schools. By 2000, children of French Canadian ancestry were as likely to attend public schools as the general population.

By looking at school participation rates at thirty year intervals, we have implicitly been comparing across generations. Figures 6a-d show how average schooling levels evolved across generations for a wider variety of ethnic groups. We define "fathers" and "sons" as members of the same ethnic group separated by a minimum of 21 years and by a maximum of 39 years. Figures $6 a$ and b show the pairs with the putative sons aged 25-34 and "fathers" aged 55-64, while in 6c and d the "sons" are 35-44 and 45-54. To avoid crowding the graphs, some "ethnic groups" are rather loosely defined (e.g. "White Anglos" or "Central Europeans"). The idea is to check how "unusual" FrancoAmericans' educational convergence was across generations.

For the United States as a whole (Figure 6a), the younger men averaged at least two more years of schooling than the older. Both generations of francophones were better educated only than blacks and Mexicans. Asians are the one broad ethnic group with exceptionally fast inter-generational improvement. For New England alone (Figure 6b), francophone fathers and sons are only slightly better educated than blacks, with Italians clearly ahead in both generations, but far behind the other white immigrant groups or native-born whites. Looking at older groups, Franco-American fathers on average were better educated than Italian fathers, and for the oldest men about as well educated as the Central and Eastern European fathers, but intergenerational progress for the francophones was much more limited. The intergenerational patterns for the older francophones are closest to those of blacks, where even many of the "sons" would have been migrants from the southern States. What we infer from Figures $6 \mathrm{~b}$ to $6 \mathrm{~d}$ is that as we "age" the members of the immigrant groups, we see for FrancoAmericans, but not Italians, the impact of maintaining the old tradition of low schooling. The oldest Italian and Central / Eastern European "fathers" would almost all have been immigrants to the US: many of their "sons" were able to escape the constraints a European childhood had imposed on the previous generation. The French Canadian fathers were initially as well, or better, educated than the new immigrants from Europe, but until the 1950s, their sons experienced below average intergenerational improvement.

Tables 4 to 7 show results for regression models which control as well as possible for other factors that could interact with ethnic origin in explaining educational attainment. These results largely confirm the impressions derived from Figures 2 to 6 . In terms of educational attainment French Canadians assimilated towards U.S. Anglo standards fairly slowly. By the year 2000, educational attainment for young adults of French Canadian descent was roughly the same as for U.S. Anglos. The 
overall change for Franco-Americans, relative to Italian-Americans, was somewhat lower. Italian immigrants were typically exceptionally poorly educated, so that quite a lot of the jump between the first and second generation seen in Tables 4 and 6 is due to the disappearance of working-age adults with less than Grade 3 education.

Table 4, based on evidence from the 1940 US census, provides us with a useful "midterm" reference point. By 1940 migration flows from both Italy and French Canada had nearly ceased. Controlling for age, state of residence, residence on a farm or in a metropolitan area, and labor force participation, the relative educational attainments of immigrant and second generation Italians and French Canadians observed in Figure 2 and Table 3 are confirmed. ${ }^{22}$ The U.S. born did substantially better than the immigrants, but the Italians experienced more catch-up. The fairly small group of native-born Italian-Americans with birth years around 1890 did particularly well. Among the second generation Franco-Americans (especially the men), the deficit relative to anglophones was roughly constant across age groups, even though many more of the youngest than oldest group would have had both parents born in the U.S. Educational progress stalled for second generation Franco-Americans. We view this as an effect of the parochial school environment and, more generally, the lack of emphasis put on education as a way to make economic progress. ${ }^{23}$

Tables 5 and 6 show the results of a similar exercise that uses 1970 census data. ${ }^{24}$ There is evidence of catch-up by younger U.S. born French speakers, but even for younger members of the third generation (U.S. born offspring of two U.S. born parents), Franco-Americans still lag English mothertongue New England residents by over a full year of schooling. For Italian-Americans of the third generation, the gap is close to zero, especially for younger males. ${ }^{25}$ The reference group is highly educated by the standards of the United States as a whole, and it is therefore asking quite a lot from second or third generation immigrants to completely close the gap, but the Italians achieved parity by $1970 .{ }^{26}$

Figures $5 \mathrm{a}$ and $\mathrm{b}$ show that in 2000, educational participation rates for those of French Canadian ancestry were roughly at the New England average. Table 7 again compares French-Canadian

\footnotetext{
${ }^{22}$ Restricting the comparison group to native-born Anglophones both born and living in New England, rather than to all U.S. born Anglophones living in New England has little impact.

${ }^{23}$ It was not unusual for the clergy to question the value of higher education, if not strongly discourage its pursuit, as in Vermette [1936].

${ }^{24}$ When we restrict the 1970 sample to metropolitan areas, which cuts the sample size approximately in half, we can add further controls for place of residence in 1970. Coefficients on ethnic identifier variables are little affected.

${ }^{25}$ To compare the estimates in this table with Figures $6 a-d$, look for example at the educational attainment of firstgeneration immigrants aged 55-64 and the 25-34 second-generation individuals.

${ }^{26}$ According to Figures $6 a$ and b, in 1970 the average years of education of Italian-origin men were very similar in New England and throughout the U.S. It is thus unlikely that less educated Italian-origin adults had moved away from New England.
} 
origin to English-speaking white native-born Americans of U.K. ancestry. We use three definitions of educational outcome (years of schooling, probability of some college attendance, and probability of having at least an undergraduate degree), given that variations in post-secondary attendance and graduation drive the variations in educational levels. Those who reported French-Canadian as their second ancestry are clearly more like the "white Anglos", whichever measure of educational attainment is used..$^{27}$ A "first ancestry/speak French penalty" affected educational attainment measured in years of completed schooling. It is less obvious in the case of having either some college or at least a B.A. degree, although some penalty is still seen for females.

There is a very large "ancestry gradient" affecting years of schooling for those aged 65 and over, and to a degree for the 55-64 age group. The educational deficit is in general considerably smaller for those reporting French-Canadian as their second ancestry. As we would expect given school attendance rates in 1940, older adults of French Canadian first ancestry had substantially less formal education than their Anglophone peers.

\section{VI) The Impact of Military Service on Franco-Americans}

There are three main reasons why the society Franco-Americans constructed up to about 1930 crumbled over the next thirty years. The economic mainstays (textile mills and shoe factories) of most of the New England towns in which they were heavily concentrated went into decline in the 1920s and collapsed in the 1930s, with only a brief revival during and just after the war. Thus youngsters growing up in this period, and their parents, had reason to think that jobs in local manufacturing would no longer be readily obtainable. The flow of immigrants from Canada declined in the 1920s, and nearly stopped in the 1930s. Few unilingual francophones were arriving, and as a result French was more likely to be seen as the language only of the older generation. Finally, and we think of particular importance for Franco-Americans, the draft in World War II drew almost all healthy young unmarried men into the armed forces and took them away from their home communities, often for several years. ${ }^{28}$ By the time the war was over, these men were used to living in English and quite possibly had married a nonfrancophone woman. Even if they returned to New England, their ties to their home neighborhood were greatly weakened. While we cannot fully distinguish the effects of these three explanations (all of which could have had an impact on people born in the 1920s), we explore possible roles service in the

\footnotetext{
${ }^{27} 6.9 \%$ (6.7\%) of all white males (females) aged 25 or more in New England report French Canadian first or second ancestry. Among those of French Canadian ancestry, 12.4\% of males and 13.8\% of females report speaking French at home. $12.6 \%$ of males and $14.4 \%$ of females report French-Canadian as their second ancestry. The fraction of French speakers drops to about $5 \%$ for individuals of both sexes aged less than 35. Proportions reporting French Canadian as their second ancestry rise to $15.7 \%$ of males and $17.2 \%$ of females. ${ }^{28}$ Women were not subject to the draft, and few Franco-American women served in the U.S. military. We ignore the effects of military service on women.
} 
U.S. Armed Forces played in speeding up the adoption of mainstream American values. Using data from the combined 1980-2000 censuses (to increase the sample size of francophones born in the early $20^{\text {th }}$ century) we look at the relationship between veteran status and four outcomes: educational attainment, marrying outside the ethnic group, living outside New England (for New England born males), and the use of French at home. ${ }^{29}$

During World War II, the U.S. selective service rules meant that extremely high proportions of very young men were drawn into the armed forces. From 1942, men were liable for the draft at 18 [Flynn, 1993, p. 62]. The youngest men were most likely to pass the physical fitness requirements and not be eligible for deferments on the basis of marriage and fatherhood or because of special occupational skills. ${ }^{30}$ As we can see from Figure 8, New England born men of French Canadian ancestry still alive in 1980, 1990 or 2000 were more likely than the average to have served in the US armed forces. $^{31}$

Two features of the selective service system help to explain a higher rate of military service for men of French Canadian background: occupational and student deferments. Few French Canadians worked in agriculture, where occupational deferments were extremely common [Flynn, 1993, pp. 6468]. We know that French Canadians were highly concentrated in the declining towns specialized in textile and footwear production. Few workers in these industries would have been considered vital for the war effort. Given their low participation rates in education past age 16, French Canadians (except those training for the priesthood) would rarely have been able to ask for deferment based on high school or college attendance. It appears from Figure 7 that these two factors outweighed any impact of an earlier age at marriage.

The U.S. armed forces were an English-only enterprise, and the impact of this immersion had clear long-term effects on living patterns of Franco-American veterans. Military service with the U.S. armed forces during World War II likely was important in loosening the constraints on pursuing postsecondary education. Figures 8a-b show that men born in the mid and later 1920s were much more likely to graduate from college than were women, with the gender gap noticeably greater than for those just younger or older. The rise in the male/female graduation ratio was much sharper than for nonfrancophone New Englanders. These results are consistent with the findings of Bound and Turner [2002] and Stanley [2003], as well as the Goldin and Margo [1992] finding of a positive impact of

\footnotetext{
${ }^{29}$ Using all three censuses gives us a sample of 4,920 French speakers born in New England between 1900 and 1915. The 2000 Census contributes only 680 observations.

${ }^{30}$ In July 1945, for the US as a whole, 70\% of registered men aged 18-25 had served in the armed forces [Smith, 1946, p. 567].

${ }^{31}$ All graphs are smoothed using a 5-year moving average.
} 
veteran status on college educated labor following both World War II and the Korean War. Figure 8 suggests that the G.I. Bill played a substantial role for New England born men of French Canadian ancestry. This seems to run counter to the evidence that men from lower socioeconomic backgrounds derived fewer benefits from the G.I. Bill [Stanley, 2003]. However, the schooling institutions imported by Franco-Americans provided extremely limited opportunities for post-secondary education. It is plausible that access for non-veteran Franco-Americans, even those from reasonably prosperous backgrounds, was more limited than for young men from ethnic groups that had more readily embraced the public school system. ${ }^{32}$

Men born in the early 1920s likely served longer in the military than did men born near the end of the decade. The more time in the armed forces, the more we expect their English-language skills improved and familiarity with U.S. society beyond the Little Canadas increased. Figure 9 shows the (surviving) men who were most likely to have been in the military by 1941 or 1942 were least often in New England in the late $20^{\text {th }}$ Century. For all other New England born veterans no such pattern is evident: simply being away from home for some period because of military service raises the probability of living away from New England by 1980, but year of birth appears unimportant. The fact that it matters for men of French Canadian ancestry and that the pattern roughly corresponds to the male-female relative college graduation rate suggests increased educational attainment induced by the G.I. Bill also facilitated moving away from New England. ${ }^{33}$

Over 1980 to 2000 , the people physically and probably emotionally closest to the traditional Franco-American communities were the New England born who stayed in New England. Two measurable characteristics of their assimilation into mainstream society are marriage outside the ethnic group and the use of English at home. Figure 10 shows the relative rate of marrying outside the ethnic group for (currently married, spouse present) veterans and non veterans, where ethnic group is again defined by self-reported first or second ancestry and the sample is restricted to New England residents. French Canadian ancestry veterans are generally more likely than non-veterans to have married a woman of another ancestry, with the highest ratios for men born in the years when military service was

\footnotetext{
${ }^{32}$ Restricting the definition of French Canadian ancestry to include only those who spoke French at home at Census time results in a similar graph, although the peaks in the male-female graduation ratios are more concentrated around the birth years of men most likely to have served in World War II, the Korean War, or the Vietnam War.

${ }^{33} \mathrm{We}$ only have one possible "instrument" for many inter-related outcomes (if one is willing to view being drafted for WW2 as an exogenous source of variation, which is arguable) and so cannot investigate these issues more formally.
} 
usually in World War II or the Korean War. ${ }^{34}$ Again, the observed peaks are likely affected by the induced education effect as well as the direct experience of war service.

Figure 11 shows the fraction of New England born adults still resident in that region in 19802000 who reported speaking French at home. More women than men reported current French usage at home, but the trend for women was clearly downward. For birth years up to about 1920, there was no declining pattern of French usage reported by men, so that reported rates of French usage at home for the two sexes were almost equal for those born about 1920. From then on, the male rate also dropped, which again coincides with the birth cohorts most likely to have served during World War II.5

The virtual closing of the border in 1930 no doubt accelerated the assimilation process, as United States born individuals of French Canadian descent who left the Little Canadas could not be replaced by new entrants. In addition, the decline of the New England textile industry encouraged the break-up of the French-speaking enclaves. However, as Figure 12 shows, according to the 1940 Census, few young Franco-Americans then lived outside New England, although the impact of these two factors should already have been substantial. If the Depression delayed departure, we would expect far more of the Franco-American young adults of 1940 to be living outside New England by 1970 (Figure 13). There was an increase over thirty years, but only from a maximum of roughly $10 \%$ to about 15\%. The 1970 proportions living outside New England rise sharply for men born in the 1920s: the World War II draft generation.

Military service in World War II (and also the Korean War) contributed significantly to speeding up assimilation. Franco-American veterans born in New England were more likely to be living outside of New England, to have married outside their ethnic group, and to be speaking English at home. The same birth cohorts that were at highest risk of serving during World War II saw the malefemale college completion ratio increase markedly. Given that better educated individuals are more mobile geographically and more likely to marry people of other ethnicities, a portion of the effects of the war described above were probably driven by the increased educational attainment made possible by the G.I. Bill.

\section{VII) Conclusions}

\footnotetext{
${ }^{34}$ Recall that we are excluding from consideration the veterans who had left New England - these men were approximately $10 \%$ more likely to have married someone of another ethnic background than the men who remained in New England.

${ }^{35}$ The rate of French usage at home near the end of the century was markedly higher for non veterans born in the 1920s. However, men with extremely limited formal education and English language skills were less likely to have served in the military in the 1940s.
} 
There was considerable clerical and political opposition to the emigration of French Canadians to New England and hostility towards the assimilation of those who moved to Protestant or totally secular patterns of living. Using census evidence, we have traced how people lived, not just what they or their social superiors thought and wrote about changing lifestyles. At the same time that the New York Times editorialists inveighed against the un-assimilable French Canadians, individuals were changing many habits. Some changes may have been made reluctantly and with a sense of guilt. A fictional emigrant (who had only two children), upon confessing to his cousins in rural Quebec that he had changed his surname from Larivière to Rivers reflected [Ringuet, 1940, p. 141]:

But if you changed your family name, the one you inherited from a long line of ancestors, it was a bit like repudiating your descent and stripping the name of its honourable reputation for hard work and persistence in the face of every obstacle, which generations of the family had built up. And if going off to the United States was a kind of desertion in any case ... this final surrender was in some ways a denial as bad as St. Peter's, an act of treason like the treason of Judas. ${ }^{36}$

Despite the proximity of Quebec and the network of institutions designed to extend the reach of French Quebec into New England, even those Franco-Americans who stayed in New England and identified themselves as French mother tongue or of French Canadian origin did eventually assimilate. Even for an immigrant group as resistant to assimilation as the French Canadians, pressures to adapt eventually dominated. Changes came slowly but the "American Way" at length had a powerful influence, and the process appears to now be effectively complete. World War II played a pivotal role in causing assimilation to enter its irreversible phase. Without the war (and the closing of the border in 1930), assimilation would likely have proceeded even more slowly. Although MacDonald's [1898] prediction of assimilation was right, the process took longer than he probably expected and was largely the result of major, unforeseeable events.

Franco-American assimilation was more gradual than Italian-American assimilation. The much lower migration costs (which would have influenced who moved to the U.S.) as well as the role of French-language parochial schools in New England were probably both important in explaining this difference. What lessons from the Franco-American experience may be useful in considering how to speed up the assimilation of Hispanic immigrants? This historical episode suggests that rapid assimilation (in less than three generations) cannot be expected. While Hispanics are not recreating the

\footnotetext{
${ }^{36}$ The 1920 census sample includes four households where parents were born in French Canada but report their last name as "Rivers". There are many examples of such name adaptations in the 1900 to 1920 Census samples.
} 
Mexican school system, a large part of the integration of Franco-Americans was an accidental byproduct of cataclysmic events. On balance, given the sheer size of the Mexican immigration, we think that a very slow and long process is to be expected. Yet, it is clear that when Franco-Americans mixed more with other Americans, the minority changed their behavior. A challenge for the U.S. is to devise ways to facilitate more interactions between the long-settled and recent immigrant communities. 


\section{References:}

Belanger, Albert A., Guide Officiel des Franco-Americains, 1935, Providence RI : Albert A. Belanger.

Betts, Julian and Magnus Lofstrom, "The Educational Attainment of Immigrants: Trends and Implications”, National Bureau of Economics Research Working Paper No. 6757, 1998, Cambridge MA.

Borjas, George J "Long-run Convergence of Ethnic Skill Differentials: The Children and Grandchildren of the Great Migration," Industrial and Labor Relations Review, Vol. 47 (1994): 553-73.

Borjas, George, "The Demand Curve is Downward Sloping: Reexamining the Impact of Immigration on the Labor Market”, Quarterly Journal of Economics, Vol. CXVIII (2003): 1335-1376.

Borjas, George and Stephen J. Trejo, "National Origin and Immigrant Welfare Recipiency", Journal of Public Economics, 50(3), 1993: 325-344.

Bothwell, Robert, Canada and the United States: The Politics of Partnership, Toronto: University of Toronto Press, 1992.

Bound, John and Sarah Turner, "Going to War and Going to College: Did World War II and the G.I. Bill Increase Educational Attainment for Returning Veterans?”, Journal of Labor Economics, vol. 20, no. 4, 2002: 784-815.

Brault, Gerard J., The French-Canadian Heritage in New England, Hanover, NH: University Press of New England, 1986.

Chambers, John Whiteclay II, To Raise an Army: The Draft Comes to Modern America, Free Press, New York, 1987.

Chiswick, Barry R. and Paul W. Miller, "Do Enclaves Matter in Immigrant Adjustments?”, mimeo, May 2003.

Dominion Bureau of Statistics, Canada Year Book, Ottawa, 1945.

Dominion Bureau of Statistics, Census of Canada, 1941, 1951, 1961, Ottawa.

Flynn, George Q., The Draft, 1940-1973, University Press of Kansas, Lawrence KS, 1993.

Gemery, Henry A., "Immigrants and Emigrants: International Migration and the US Labor Market in the Great Depression," in Timothy J. Hatton and Jeffrey G. Williamson, Migration and the International Labor Market 1850-1939, London, Routledge, 1994, pp. 175-199.

Goldin, Claudia, "America's Graduation from High School: The Evolution and Spread of Secondary Schooling in the Twentieth Century", The Journal of Economic History, Vol.58, No. 2 (June 1998): 345-374.

Goldin, Claudia and Lawrence F. Katz, "Human Capital and Social Capital: The Rise of Secondary Schooling in America, 1910 to 1940", Journal of Interdisciplinary History, 29, 1999: 683-723.

Goldin, Claudia and Margo, Robert A. "The Great Compression: The Wage Structure in the United States at Mid-Century" Quarterly Journal of Economics, Vol. CVII (1992): 1-34.

Green, Alan, Mary MacKinnon, and Chris Minns, "Conspicuous by their Absence: French-Canadians and the Settlement of the Canadian West," Journal of Economic History, Vol. 65 (2005), pp. 822-49. 
Hamon, Father Edouard, Les Canadiens-français de la Nouvelle-Angleterre, Quebec City, Hardy, 1891.

Hareven, Tamara, Family Time and Industrial Time : The Relationship Between the Family and Work in a New England Industrial Community, New York, Cambridge U.P., 1982.

Huntington, Samuel P., “The Hispanic Challenge”, Foreign Policy, 2004: 30-45.

Lemieux, Thomas and David Card, "Education, Earnings, and the 'Canadian G.I. Bill”, Canadian Journal of Economics, vol. 34 \#2, May 2001, pp. 313-344.

Lines, Kenneth, British and Canadian Immigration to the United States since 1920, San Francisco, R\&E Research Associates, 1978.

Linteau, Paul-André, René Durocher, Jean-Claude Robert, and François Ricard, Quebec Since 1930, (Robert Chodos and Ellen Garmaise, trans.), Toronto: James Lorimer \& Company, 1991.

MacDonald, William, “The French Canadians in New England”, Quarterly Journal of Economics, Vol. XII, \# 3, $1898:$ 245-279.

Massachusetts Bureau of Statistics of Labor, Twelfth Annual Report, Boston, 1881.

Massachusetts Bureau of Statistics of Labor, Thirteenth Annual Report, Boston, 1882.

Paquet, Gilles and Wayne Smith. "L'émigration des Canadiens-français vers les Etats-Unis, 1790-1940: Problématique et coups de sonde”, L’Actualité économique, Vol. 59, No. 3, sept. 1983: 423-453.

Pariseau, Jean and Serge Bernier, French Canadians and Bilingualism in the Canadian Armed Forces, Vol. 1, Department of National Defence, Directorate of History, Ottawa, 1988.

Perlmann, Joel, Ethnic Differences: Schooling and Social Structure Among the Irish, Italians, Jews, and Blacks in an American City, 1880-1935, New York: Cambridge University Press, 1988.

Petrin, Ronald A., French Canadians in Massachusetts Politics, 1885-1915: Ethnicity and Political Pragmatism, Philadelphia: Balch Institute Press, 1990.

Ramirez, Bruno, Crossing the $49^{\text {th }}$ parallel: Migration from Canada to the United States, 1900-1930, Ithaca, Cornell University Press, 2001.

Ringuet, Trente Arpents (Thirty Acres), translated to English by Felix and Dorothea Walter, Toronto, McLelland and Stewart, 1940.

Roby, Yves, Les Franco-Américains de la Nouvelle-Angleterre (1776-1930), Septentrion, Montréal, 1990.

Roby, Yves, Les Franco-Américains de la Nouvelle-Angleterre : rêves et réalités, Septentrion, Sillery, QC, 2000 .

Ruggles, Steven, Matthew Sobek, et al. Integrated Public Use Microdata Series: Version 3.0. Minneapolis, MN: Minnesota Population Center, 2004: http://www.ipums.org.

Sager, Eric W. The National Sample of the 1901 Census of Canada: User's Guide. Canadian Families Project, University of Victoria, mimeo, 2002. [and computer file]

Smith, Mapheus, "The Differential Impact of Selective Service Inductions on Occupations in the United States,” American Sociological Review, Vol 11, \# 5 (Oct. 1946): 567-572. 
Stanley, Marcus, "College Education and the Midcentury GI Bills" Quarterly Journal of Economics, Vol. CXVIII, Issue 2 (2003): 671-708.

Theriault, George French, The Franco-Americans in a New England Community: An Experiment in Survival, Ph.D. Dissertation, Harvard, 1951 (published under the same title by Arno Press, N.Y, 1980).

Trejo, Stephen J., "Intergenerational Progress of Mexican-Origin Workers in the U.S. Labor Market", Journal of Human Resources, Vol. 38, No. 3 (Summer 2003): 467-489.

Truesdell, Leon, The Canadian Born in the United States: An Analysis of the Statistics of the Canadian Element in the Population of the United States 1850 to 1930, Toronto, Ryerson, 1943.

U.S. Department of Commerce, Statistical Abstract of the United States, Washington, GPO, 1946, 1952, 1962.

United States Immigration Commission, Immigrants in Industries, Vol. 20; The Children of Immigrants in Schools, Vols. 30-32, Washington Government Printing Office, 1911.

Urquhart, M.C. and K.A.H. Buckley (eds) Historical Statistics of Canada, Macmillan, Toronto, 1965.

Vermette, Father Joseph S., "Par l'école", in Les Franco-Américains peints par eux-mêmes. Éditions Albert Lévesque, Montreal, 1936.

Vicero, Ralph D. Immigration of French Canadians to New England, 1840-1900: A Geographical Analysis, Ph.D. Dissertation, University of Wisconsin, 1968.

Warner, W. Lloyd and Leo Srole, The Social Systems of American Ethnic Groups (Yankee City Series, Vol. III), New Haven CT: Yale UP, 1945. 